\title{
Identification and Quantification of Intracoordination Water in Insoluble Pectinates $\mathrm{Cu}^{2+}$ and $\mathrm{Pb}^{2+}$
}

\section{Nelli Shalikovna Kajsheva, Alexander Shalikovich Kajshev, Borisovna Anna Samoryadova, Kristina Vladimirovna Smolenskaya, Galina Vladimirovna Smolenskaya}

Pyatigorsk Medical and Pharmaceutical Institute-A Branch of Federal State-Funded Educational Institution of Higher Vocational Education VolgSMU of Health Ministry of the Russian Federation, Pyatigorsk, Russia

Email: caisheva2010@yandex.ru

How to cite this paper: Kajsheva, N.S., Kajshev, A.S., Samoryadova, B.A., Smolenskaya, K.V. and Smolenskaya, G.V. (2017) Identification and Quantification of Intracoordination Water in Insoluble Pectinates $\mathrm{Cu}^{2+}$ and $\mathrm{Pb}^{2+}$. American Journal of Analytical Chemistry, 8, 210-224. https://doi.org/10.4236/ajac.2017.83017

Received: December 25, 2016

Accepted: March 10, 2017

Published: March 13, 2017

Copyright ( 2017 by authors and Scientific Research Publishing Inc. This work is licensed under the Creative Commons Attribution International License (CC BY 4.0).

http://creativecommons.org/licenses/by/4.0/

\begin{abstract}
By derivatography in insoluble pectins $\mathrm{Cu}^{2+}\left(\mathrm{PCu}^{2+}\right)$ and $\mathrm{Pb}^{2+}\left(\mathrm{PPb}^{2+}\right)$, the presence of "a high-temperature component" $\left(150^{\circ} \mathrm{C}-165^{\circ} \mathrm{C}\right)$ is established. During potentiometric alkalimetric titration of $\mathrm{PCu}^{2+}$ and $\mathrm{PPb}^{2+}$, endpoints are established at $\mathrm{pH}$ accordingly 4.87 and 4.95, proving acid properties of PM. Obtained data show the presence of water in the internal sphere of PM. Considering the loss of this water and the known ratio of metal cations and monomers of pectin $\left(\mathrm{L}^{-}\right)$, the simplest formulas of pectins are established: $\left[\mathrm{Cu}\left(\mathrm{L}^{-}\right)_{2}\left(\mathrm{H}_{2} \mathrm{O}\right)_{2}\right],\left[\mathrm{Pb}\left(\mathrm{L}^{-}\right)_{2}\left(\mathrm{H}_{2} \mathrm{O}\right)_{4}\right]$.
\end{abstract}

\section{Keywords}

Coordination Connections, Pectinates of Metals, Ions of Copper (II), Ions of Lead (II), Composition, Derivatography, Potentiometry

\section{Introduction}

Effect of heavy metals (HM) on a human is carried out in the natural circulation in the biosphere under conditions of environmental and plant pollution (air, water, soil) and plants. Even herbal medicines are contaminated by impurities of $\mathrm{HM}$ by an average of $27 \%$ [1]. Environmental degradation arises from the anthropogenic factors: the widespread use of HM compounds in chemical engineering, metallurgy, electronics, nuclear energy, mechanical engineering, it leads to the expansion of production of industrial and consumer products containing various HM [2]. Environmental problems cause contamination of food. An additional source of intoxication is a production environment for those who are 
involved in the processing or use of HM compounds [2].

The problem of HM enrichment is solved with the help of decontamination protocols based on the principles of: termination of toxic poisoning of a body, of support of detoxification organs and drainage, of stimulating the elimination of toxins, of the increase of susceptibility of patients to detoxification [3] [4]. General support of regulation and detoxification requires the presence of cofactors (minerals, vitamins, amino acids). The means of the basic protocol include drugs that support the liver and kidneys, as well as tissue drainage through the lymphatic system. The supported protocol ensures the activation of the detoxification organs. The release of a body from HM is carried out by increasing of natural physiological processes (vomiting, gastric lavage, intestinal cleansing, forced diuresis, hyperventilation), artificial detoxification (hemodialysis, peritoneal dialysis, hemosorbtion, blood transfusions), by the method of antidote therapy [5]. When poisoning antidotes gradually connect HM cations entering the body and forming complexes with enzymes, some antidotes are specific to a particular $\mathrm{HM}$, so for their rational application it is necessary to know what HM caused the poisoning. If you select a wrong antidote or if it will be overdose poisoning of an antidote can be, so the data of clinical and laboratory research of a HM, which is in a body, are important for the proper selection and application of an antidote. The requirements for antidotes are reduced to the following rules [6]:

- Antidotes form strong compounds with HM to take away the active center of enzymes and to get out from a body; antidotes with 5-6-membered rings, which can form coordination compounds (CC) with metals and which have several electron-donating groups, preferably chromophores providing strong, practically complete compound of TM, satisfy this requirement;

- The ability of antidotes and their CC with HM to pass through a cell membrane, for which they should be electrically neutral or bear a small charge to dissolve in the lipid membranes;

- Nontoxicity of antidotes and CC with HM formed by them;

- Selective compound of HM and biogenic metals (BM) by antidotes due to various stability of formed CC: formed CC must be more stable with HM than with BM to avoid the elimination BM from biological systems.

Considering these requirements for the different mechanisms of functions of chemical antidotes there are the following advantages and disadvantages.

1) Chelators binding HM in a little dissociated and easily soluble CC in water (chelates) [7]-[13]: tetatsin-calcium, pentatsin, ferrocin, disodium edetate, trimefatsin, deferoxamine, deferiprone, penicillamine.

Advantages: a wide spectrum of detoxication action for a number of $\mathrm{HM}(\mathrm{Pb}$, $\mathrm{Cd}, \mathrm{V}, \mathrm{Cr}, \mathrm{Hg}, \mathrm{Cs}, \mathrm{U}, \mathrm{Y}, \mathrm{Ce}, \mathrm{Th}, \mathrm{Ni}, \mathrm{Cu}, \mathrm{Pu}, \mathrm{Rb}, \mathrm{Zr}, \mathrm{Nb})$, even bound with enzymes; high CC durability with HM (logarithm of the durability constant $(\lg \beta)$ 14.0 - 19.0); rapid renal elimination.

Disadvantages: forming with $\mathrm{BM}(\mathrm{Ca}, \mathrm{Mg}, \mathrm{Co}, \mathrm{Fe}, \mathrm{Zn}, \mathrm{Mn})$ very strong CC (lg $\beta 5.0-11.0$ ), leading to a decrease of hemoglobin composition, $\mathrm{Fe}$, vitamin $\mathrm{B}_{12}$, $\mathrm{Ca}$ in blood, $\mathrm{P}$ (phosphorus) in bones and blood; easy absorption of water- 
soluble CC from a gastrointestinal tract and strengthening of effects of toxic nephrosis.

2) The antidotes containing sulfhydryl (mercapto), and easily forming with HM-soluble compounds [7] [12] [13]: unitiol, suktsimer, penicillamine, sodium thiosulfate.

Advantages: a wide spectrum of detoxication action for a number of $\mathrm{HM}(\mathrm{Hg}$, $\mathrm{Bi}, \mathrm{Cu}, \mathrm{Au}, \mathrm{Ni}, \mathrm{Cr}, \mathrm{Ag}, \mathrm{Pb}, \mathrm{Cd}$ ), even bound with enzymes; high $\mathrm{CC}$ durability with HM ( $\lg \beta 14.0$ - 19.0); rapid renal elimination.

Disadvantages: forming with $\mathrm{BM}(\mathrm{Zn}, \mathrm{Fe})$ very durable compounds $(\lg \beta 5.0$ $11.0)$, the consequences of which are similar to those complexes described above.

3) The antidotes absorbed HM [7] [14] [15] [16]: carbon sorbents based on a synthetic polymer (SKN, SUGS, FAS, SKS, SCAN) and on the basis of vegetable raw materials (carbol, AUE, KAU, BAU), zeolite-containing rocks (shivyrtuin, hongurin), zeolite-containing (zeosorb), lignin, polyphepanum.

Advantages: elimination of HM; high sorption capacity.

Disadvantages: elimination of BM (Fe), vitamins, hormones, lipids, proteins; HM desorption from the surface of adsorbents, which requires the prescrition of laxatives; detoxification only in the gastrointestinal tract.

4) The antidotes accelerating biotransformation of HM to form insoluble and non-toxic metabolites [7] [17] [18] [19]: sodium thiosulfate, hydroxyapatites, polioxymes, ferrokolane, povargen, zinam, sodium polyphosphate, magnesium sulfate.

Advantages: formation of durable compounds with HM.

Disadvantages: formation of durable compounds with BM.

5) The antidotes, enhancing neutralizing function of a liver [7] [14] [15] [16]: carbopekt (a mixture of activated carbon and citrus pectin), the mixture of vaul and sodium alginate with a cation or polyantimonin, plant gatherings, containing polysaccharides, flavonoids (kidney tea, walnuts, Siberian stone pine, ginseng).

Advantages: formation of durable compounds with HM.

Disadvantages: formation of durable compounds with BM.

6) Pectins occupy a special position because of the specific structural and physicochemical properties [6] [20]-[25]:

- in their molecules there are more coordinating groups (carboxyl, hydroxyl groups, the glycosidic bond, oxygen atom of the pyranose cycle) than it is required for the binding of $\mathrm{HM}$, which can select the group to form a more durable CC;

- the tendency to the formation of CC less than conventional chelators have, (and, consequently, the durability of products) due to the rigidity of the circuit, limiting the freedom of its bending and twisting;

- solubility or insolubility of formed by pectins CC with metals depends on the degree of polymerization and the concentration of pectin, therefore, pectins can act in a gastrointestinal tract and in body fluids.

The consequence of these features is that the $\lg \beta$ of $\mathrm{CC}$ of BM with pectins $(1.2-2.4)$ is much lower than with amino acids, nucleotides and enzymes in a 
human body (for Mg 4.0 - 4.8, Mn 4.5 - 6.1, Fe 6.5 - 8.5, Co 7.2 - 10.2, Zn 8.1 10.2 [12] [13]), and with the above mentioned mercaptan compounds and versenes (5.0 - 11.0); it shows the impossibility of elimination of BM from biological substrates by pectins, unlike comparable groups of antidotes. At the same time, pectins form relatively durable CC with $\mathrm{HM}$ in the solution $(\lg \beta 6.6-7.9)$ and in the insoluble state $(\lg \beta 5.5$ - 7.8) [6]. The ability of pectin to bind and eliminate from biological substrates of $\mathrm{HM}(\mathrm{Pb}, \mathrm{Sr}, \mathrm{Cs}, \mathrm{Ge}$ et al.) when keeping the balance of BM (Ca, Mg, Zn, Co) was proved in animal experiments [22] [23] [25] and in a clinical setting on humans. The analysis of clinical material showed normalization of coagulogram, activity of transaminases, quantity of bilirubin, processes electrolytic and cholesterol exchange, the level of reduced glutathione.

The detoxication action of pectin enhances by their adsorption, hepatoprotective and water retaining properties. Pectin is practically non-toxic and biologically compatible with a human body [6].

Despite of the study of the structure of such CC as pectinates of metals (PM) [6], there is the problematic question of the composition of intracoordination water which can have an effect on solubility, bioavailability of PM and therapeutic dose of pectins as an antidote. In PM produced in aqueous reaction medium [26] water molecules may be contained in the inner or the outer sphere of CC or be capillary bound (adsorbed) [27]. As far as pectins play the role of chelating in HM binding, regardless of the presence or absence of water molecules, determining of intracoordination water composition is of interest from the viewpoint of calculation of pectin dose-reagents which bound HM. Ignoring the composition of water molecules in any CC may lead to diminishment of doses of an antidote which is in the lack in regard to HM.

To determine water in PM there are analytical methods: polarography [28] and IR spectroscopy [29] [30]. However, their use does not allow to quantitatively determine the water composition and to set its presence or differentiate its position CC composition. Dehydration of PM $\left(10^{-5} \mathrm{~mm}\right.$ of mercury, $\left.185^{\circ} \mathrm{C}\right)$ [30] contributes to the loss of the adsorption and coordination water, and the subsequent processing of $\mathrm{CC}$ by water does not allow to objectively evaluate the water molecules participation in the formation of PM. In addition, the use of these methods is limited by the interfering effect of other structural components in CC.

The durability of bonds depends on the position of water molecules: the most durable bond is connection of the water molecules with metal ions in the inner sphere of CC, less solid-connection of water molecules in the outer sphere of CC, the weakest-connection of the adsorption water. [28] In this regard, one can assume ratio of bond durability with the temperature of their abruption. Determination of these temperatures and the corresponding mass loss, which forms the basis of the method of thermogravimetry, prompted us to apply this method to determine the position of water as part of CC and the determination of its quantitative composition.

The goal of the study is to determine the presence, position and number of 
water molecules in setting of the molar composition of insoluble pectinates $\mathrm{Cu}^{2+}$ $\left(\mathrm{PCu}^{2+}\right)$ and $\mathrm{Pb}^{2+}\left(\mathrm{PPb}^{2+}\right)$ by methods of derivatography and potentiometry.

\section{Experimental Part}

The object of the study is a beet pectin (satisfying the requirements of short-term certified pharmacopeial description 42-3433-99 "Pectin") with an average molar mass of $3200 \mathrm{~kg} / \mathrm{mol}$ and a dissociation constant in water $3.2 \times 10^{-4}$ and it contains $14.4 \%$ of free carboxyl groups, $9.2 \%$ of the methylated carboxyl groups [6] [31]. In the research we use acetates of $\mathrm{Cu}^{2+}\left(\mathrm{ACu}^{2+}\right)$ и $\mathrm{Pb}^{2+}\left(\mathrm{APb}^{2+}\right)$ ("reagent grade"). $\mathrm{PM}$ are obtained in solid state by mixing pectin $\left(7.8 \times 10^{-4} \mathrm{~mol} / \mathrm{l}\right)$ and $\mathrm{AM}(0.1 \mathrm{~mol} / \mathrm{l})$ in a volume ratio $10: 1$, by filtration of precipitations, purification and drying at temperature of $70^{\circ} \mathrm{C} \pm 5^{\circ} \mathrm{C}$ for 3 hours [26]. $\mathrm{PCu}^{2+}$ is green, $\mathrm{PPb}^{2+}$ is light brown.

The study of the composition $\mathrm{PCu}^{2+}$ and $\mathrm{PPb}^{2+}$ compared with pectin and $\mathrm{AM}^{2+}$ is carried out in stages. Using variants of thermal analysis: differential thermal (DTA), differential thermogravimetric (DTGA) and thermogravimetric (TGA) on a derivatograph "Q-1500" (Hungary, "MOM") in the temperature range $20^{\circ} \mathrm{C}-1000^{\circ} \mathrm{C}$ in a dynamic atmosphere of air at a heating rate of substances $10 \mathrm{deg} . / \mathrm{min}$, at the speed of paper movement $5 \mathrm{~mm} / \mathrm{min}$, at using aluminium oxide as a standard, the presence of "high-temperature" component in solid PM weighing about $0.5-0.6 \mathrm{~g}$ (accurately weighed amount) was determined. Selection of high heating rate is conditioned by the need to prevent PM structural change in the course of writing of thermal curves: water molecules transition in sphere of the coordination ion [32]. In order to determine the possible formation of hydroxycomplexes due to pectinates, by the method of potentiometric titration at $\mathrm{pH}$-meter " $\mathrm{pH}-340$ " (reference electrode is a silver chloride, indicator electrode is glass) $50 \mathrm{ml}$ of aqueous suspensions $\mathrm{PCu}^{2+}(8.6 \times$ $\left.10^{-4} \mathrm{~mol} / \mathrm{l}\right)$ and $\mathrm{PPb}^{2+}\left(7.3 \times 10^{-4} \mathrm{~mol} / \mathrm{l}\right)$ prepared from samples dried at $120^{\circ} \mathrm{C}$ for 8 hours was titrated by sodium hydroxide solution $0.1 \mathrm{~mol} / \mathrm{l}$. Differentially in the graphic system " $(\Delta \mathrm{pH} / \Delta \mathrm{V})-\mathrm{V}_{\text {titrant }}$ " [33] an endpoint was determined. For comparison, we used aqueous solutions $(\mathrm{mol} / \mathrm{l})$ of pectin $\left(6.3 \times 10^{-4}\right), \mathrm{ACu}^{2+}(5.1$ $\left.\times 10^{-3}\right), \mathrm{APb}^{2+}\left(6.1 \times 10^{-3}\right)$ prepared beforehand freed from adsorbed water $\left(120^{\circ} \mathrm{C}, 8\right.$ hours) of substances. When setting (by thermal curves) the presence of "high-temperature" component (with a temperature of $>150^{\circ} \mathrm{C}$ ) and the formation (by potentiometric curves) of hydroxycomplexes ( $\mathrm{pH}$ at the endpoint $<5$ ), indicating the presence of intracoordination water, in the $\mathrm{PM}$ dried at $120^{\circ} \mathrm{C}$ for 8 hours its content was determined by TGA, built in the graphical system "The loss of water, mmol-the temperature of dehydration ${ }^{\circ} \mathrm{C}$ ", then the molar composition of PM was calculated.

\section{Results and Its Discussion}

Analysis of the composition $\mathrm{PCu}^{2+}$. Comparative analysis of pectin thermograms (Figure 1), $\mathrm{ACu}^{2+}$ (Figure 2) and $\mathrm{PCu}^{2+}$ (Figure 3) shows significant differences in thermal effects, the nature of which is indicated in Table 1. 


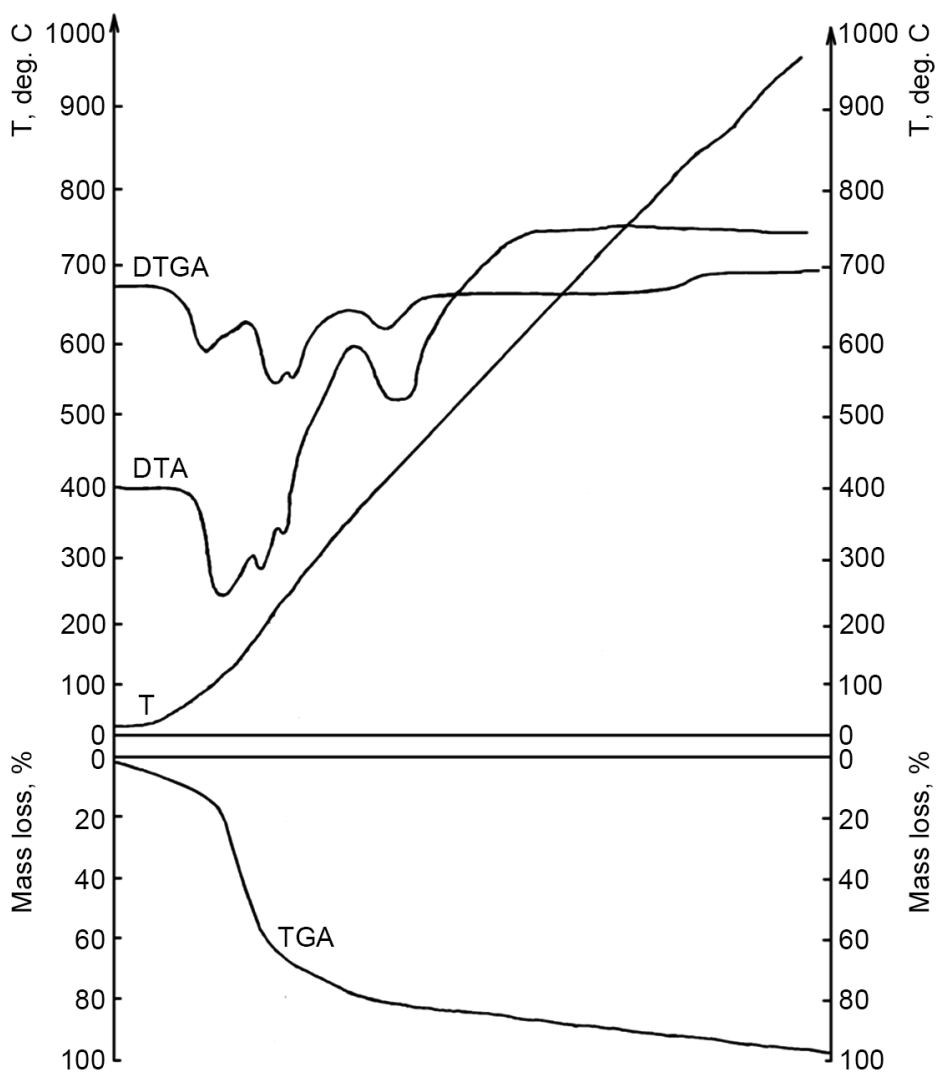

Figure 1. Pectin thermogram.

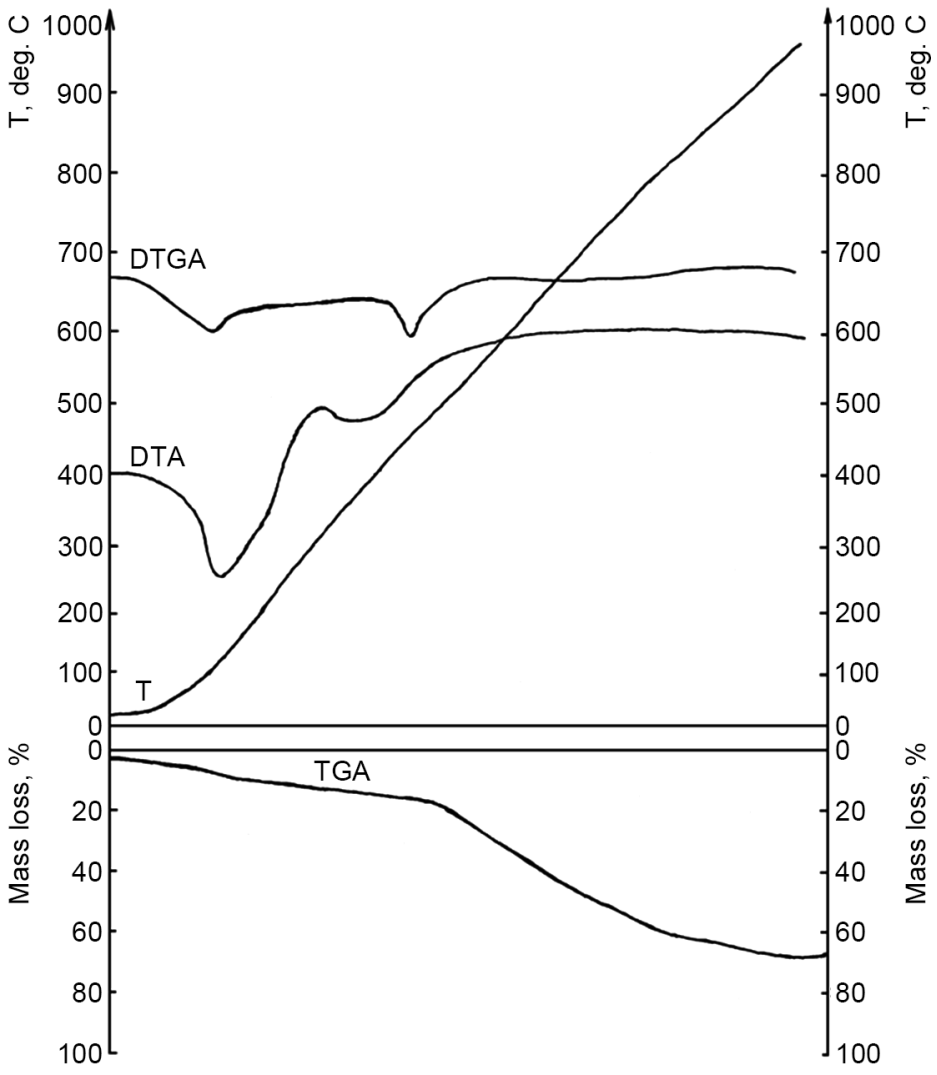

Figure 2. Thermogram $\mathrm{ACu}^{2+}$. 


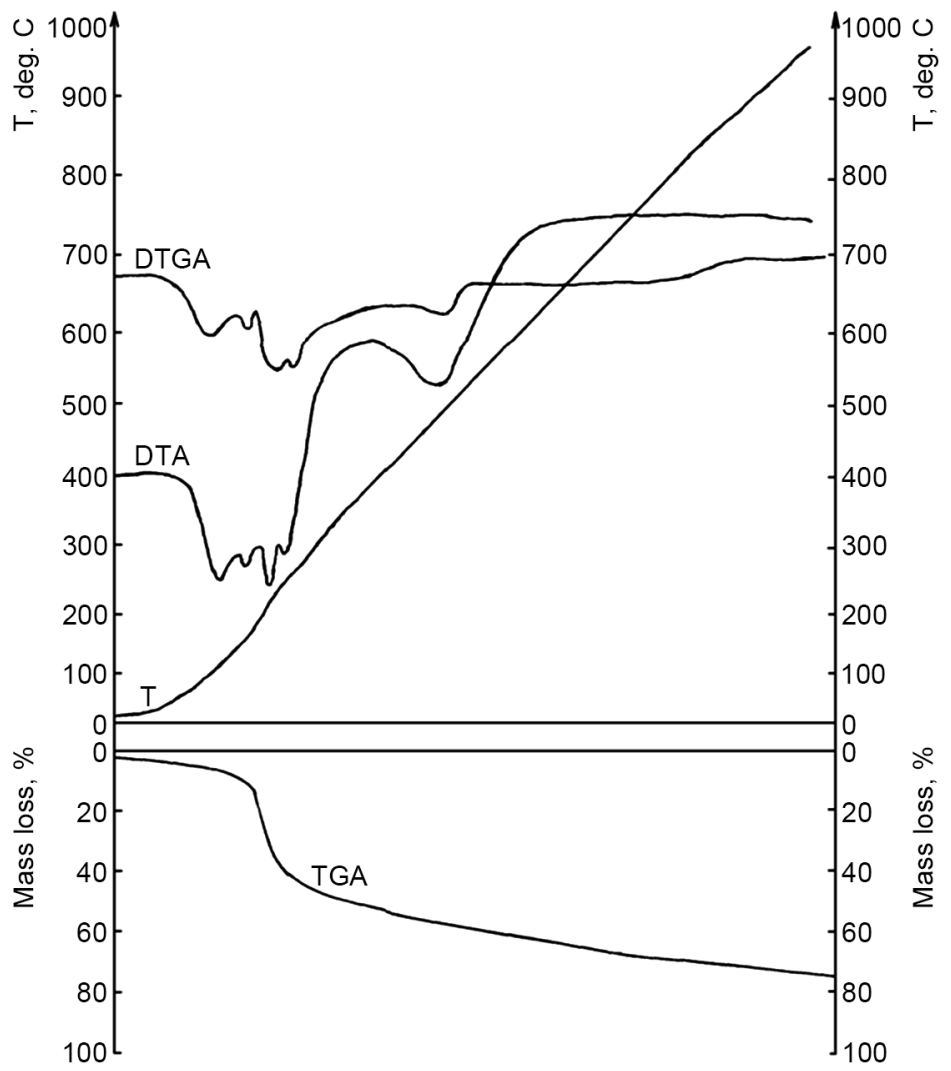

Figure 3. Thermogram $\mathrm{PCu}^{2+}$.

Table 1. Thermal characteristics $\mathrm{PCu}^{2+}$ and reagents.

\begin{tabular}{|c|c|c|c|}
\hline $\begin{array}{l}\text { Effect of DTA } \\
\left(\mathrm{T}_{1}-\mathrm{T}_{2}\right),{ }^{\circ} \mathrm{C}\end{array}$ & Nature of the effect & $\begin{array}{l}\text { Effect of DTGA } \\
\left(\mathrm{T}_{1}-\mathrm{T}_{2}\right),{ }^{\circ} \mathrm{C}\end{array}$ & $\begin{array}{c}\text { Total weight } \\
\text { loss, } \%\end{array}$ \\
\hline \multicolumn{4}{|c|}{ Pectin } \\
\hline $100-115(\max 113)$ & $\downarrow$ desolvation & $80-105(\max 105)$ & \multirow{4}{*}{98.0} \\
\hline $190-210(\max 200)$ & $\downarrow$ destruction of carboxyl groups & $210-230(\max 230)$ & \\
\hline $230-260(\max 240)$ & $\downarrow$ destruction for 1,4-glycosidic bonds & $255-270(\max 265)$ & \\
\hline $420-450$ & $\downarrow$ destruction & $410-415(\max 415)$ & \\
\hline \multicolumn{4}{|c|}{$\mathrm{ACu}^{2+}$} \\
\hline $115-120(\max 118)$ & $\downarrow$ desolvation & $110-115(\max 115)$ & \multirow{2}{*}{68.0} \\
\hline $300-430(\max 400)$ & $\downarrow$ destruction with melting & $320-450(\max 390)$ & \\
\hline \multicolumn{4}{|c|}{$\mathrm{PCu}^{2+}$} \\
\hline $115-120(\max 120)$ & $\downarrow$ desolvation & $90-115(\max 110)$ & \\
\hline $155-160(\max 160)$ & $\downarrow$ desolvatin & $150-165(\max 165)$ & \\
\hline $200-220(\max 215)$ & $\downarrow$ destruction of carboxyl groups & $215-230(\max 225)$ & 75.0 \\
\hline $240-260(\max 255)$ & $\downarrow$ destruction for 1,4-glycosidic bonds & $250-265(\max 260)$ & \\
\hline $470-500$ & $\downarrow$ destruction & $460-480(\max 475)$ & \\
\hline
\end{tabular}

Note here and in Table 3: " $\downarrow$ "-an endothermic effect; "max" is the maximum point of the thermal effect; $\left(T_{1}-T_{2}\right)$ is a temperature interval of beginning and ending of the effect. 
The first heat effect (endothermic), observed for all substances, refers to the temperature range $80^{\circ} \mathrm{C}-115^{\circ} \mathrm{C}(\mathrm{DTGA}), 100^{\circ} \mathrm{C}-120^{\circ} \mathrm{C}$ (DTA). The results of the quantitative determination of water by drying $\left(120^{\circ} \mathrm{C}, 8\right.$ hours): mass reduction of pectin from $0.60802 \mathrm{~g}$ to $0.50344 \mathrm{~g}$ (water loss $17.2 \%$ ), $\mathrm{ACu}^{2+}$-from $0.52315 \mathrm{~g}$ to $0.47607 \mathrm{~g}$ (water loss $9.0 \%$ ), $\mathrm{PCu}^{2+}$-from $0.58683 \mathrm{~g}$ to $0.54340 \mathrm{~g}$ (water loss 7.4\%) shows that the effect of the first heat loss is associated with loss of capillary connected (adsorption) water. Unlike pectin (Figure 1) and $\mathrm{ACu}^{2+}$ (Figure 2), for $\mathrm{PCu}^{2+}$ (Figure 3) we found the second endothermic effect (DTGA: $150^{\circ} \mathrm{C}-165^{\circ} \mathrm{C}$; DTA: $155^{\circ} \mathrm{C}-160^{\circ} \mathrm{C}$ ) which may also associated with water loss. Other observed endothermic effects are determined by destruction of the organic pectin part and $\mathrm{PCu}^{2+}$ by carboxyl groups, glycoside bonds. Subsequent increase of temperature led to the complete decomposition of all substances. Thus, the analysis of thermal curves showed that pectin, $\mathrm{ACu}^{2+}$ and $\mathrm{PCu}^{2+}$ contain adsorption water splitting out at a low temperature and $\mathrm{PCu}^{2+}$ has also a "high temperature" component.

Assuming that the "high temperature" component in $\mathrm{PCu}^{2+}$ are molecules of intracoordination water, $\mathrm{PCu}^{2+}$, practically completely dehydrated by adsorption water at a temperature of $120^{\circ} \mathrm{C}$ (upper limit of the endothermic effect) for 8 hours, was alkalimetrically titrated in comparison with pectin and $\mathrm{ACu}^{2+}$.

If during pectin titration (Figure 4) the endpoint occurs as $\mathrm{pH} 9.14(\Delta \mathrm{pH} / \Delta \mathrm{V}$ $=28.70), \mathrm{ACu}^{2+}$ (Figure 5, curve 1) $-\mathrm{pH} 6.42(\Delta \mathrm{pH} / \Delta \mathrm{V}=2.78)$, then during titration it occurs as $\mathrm{PCu}^{2+}$ (Figure 5, curve 2) $-\mathrm{pH} 4.87(\Delta \mathrm{pH} / \Delta \mathrm{V}=1.62)$.

Of all the substances only $\mathrm{PCu}^{2+}$ is characterized by the endpoint in an acidic media having $\mathrm{pH}$ significantly below $\mathrm{pH}$ and pectin and $\mathrm{ACu}^{2+}$. The obtained data suggest that occurring of acidic $\mathrm{PCu}^{2+}$ properties when dealing with alkali, and it is possible only due to water molecules, the acidic properties of which are increased as a result of coordination with ions of $\mathrm{Cu}^{2+}$.

Thus, determination of "high-temperature" component $\left(150^{\circ} \mathrm{C}-165^{\circ} \mathrm{C}\right)$ in $\mathrm{PCu}^{2+}$ and demonstration of its acidic properties ( $\left.\mathrm{pH} 4.87\right)$ proves the existence of water molecules in the internal sphere of $\mathrm{PCu}^{2+}$ and it is not typical for reagents.

The calculated according TGA amount of water removed from the decomposed substances are given in Table 2.

Unlike pectin (Figure 6) and $\mathrm{ACu}^{2+}$ (Figure 7), on TGA of $\mathrm{PCu}^{2+}$ (Figure 8) a "ground" for intracoordination water is clearly observed (dehydration temperature of $150^{\circ} \mathrm{C}-165^{\circ} \mathrm{C}$ ), its amount was $2.42 \mathrm{mmol}$ (or $0.04356 \mathrm{~g}$ ).

The mass difference of the $\mathrm{PCu}^{2+}(0.54340 \mathrm{~g})$ and intracoordination water $(0.04356 \mathrm{~g})$ aquacomplex showed a mass of anhydrous $\mathrm{PCu}^{2+}(0.49984 \mathrm{~g})$. Considering the molar ratio in $\mathrm{PCu}^{2+}$ of $\mathrm{Cu}^{2+}$ ions and galacturonic acid residues (monomers of pectin, L) 1:2 (15.46 wt\%:84.54 wt\%) [6], the content of $\mathrm{Cu}^{2+} \mathrm{ca}$ tions $(0.07728 \mathrm{~g}$ or $1.217 \mathrm{mmol})$ and $\mathrm{L}(0.42256 \mathrm{~g}$ or $2.415 \mathrm{mmol})$ is calculated. Thus, the composition of $\mathrm{PCu}^{2+}$, released from the adsorption water, is expressed by the following ratios of $\mathrm{Cu}^{2+}$ ions, $\mathrm{L}^{-}$and coordination water molecules: by mass (g) - 0.07728:0.42256:0.04356; by amount (mmol)-1.217:2.415:2.420 or 1:2:2, 


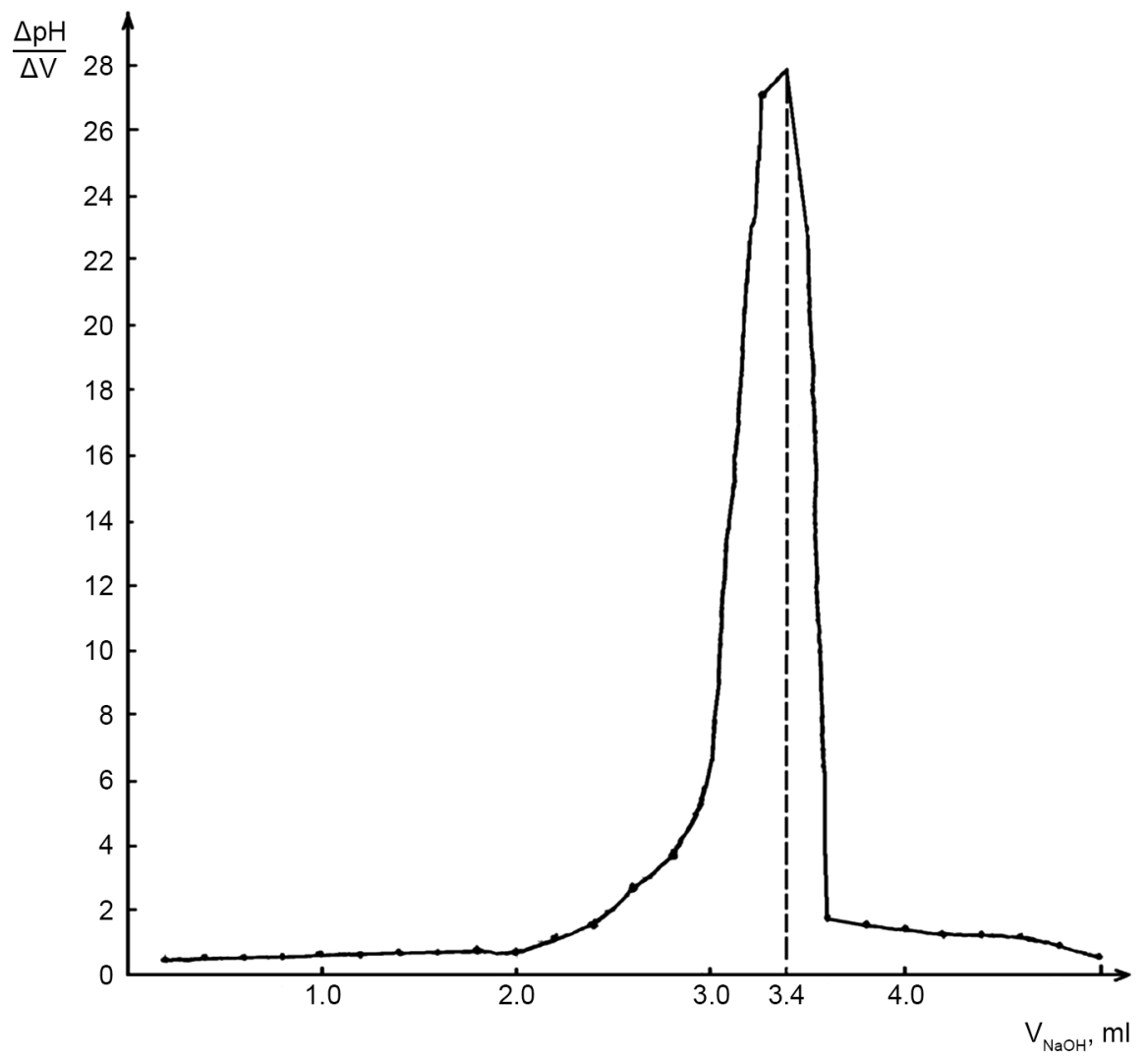

Figure 4. The curve of alkalimetric pectin titration.

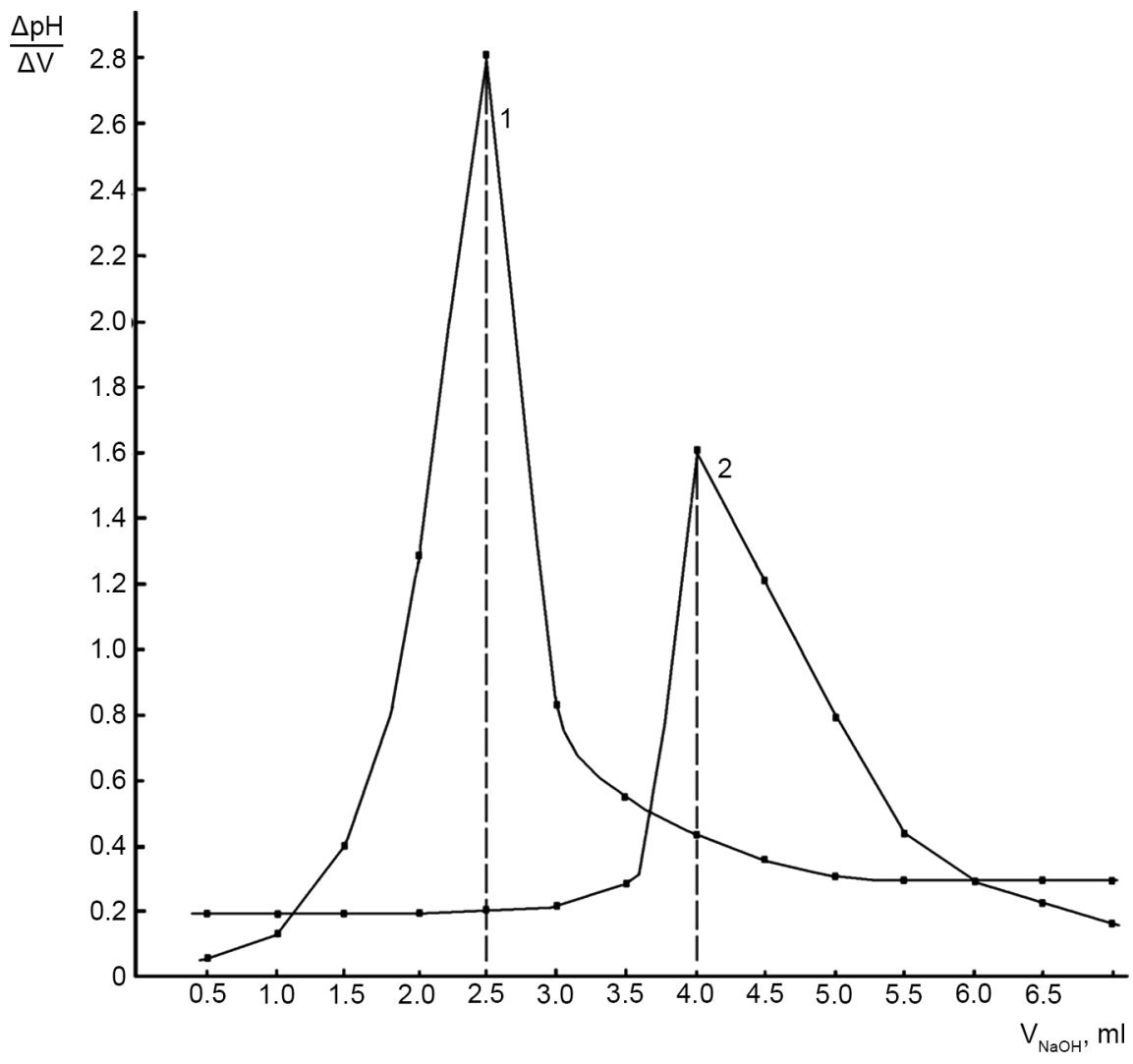

Figure 5. The curves of alkalimetric titration $\mathrm{ACu}^{2+}$ (curve 1) and $\mathrm{PCu}^{2+}$ (curve 2). 


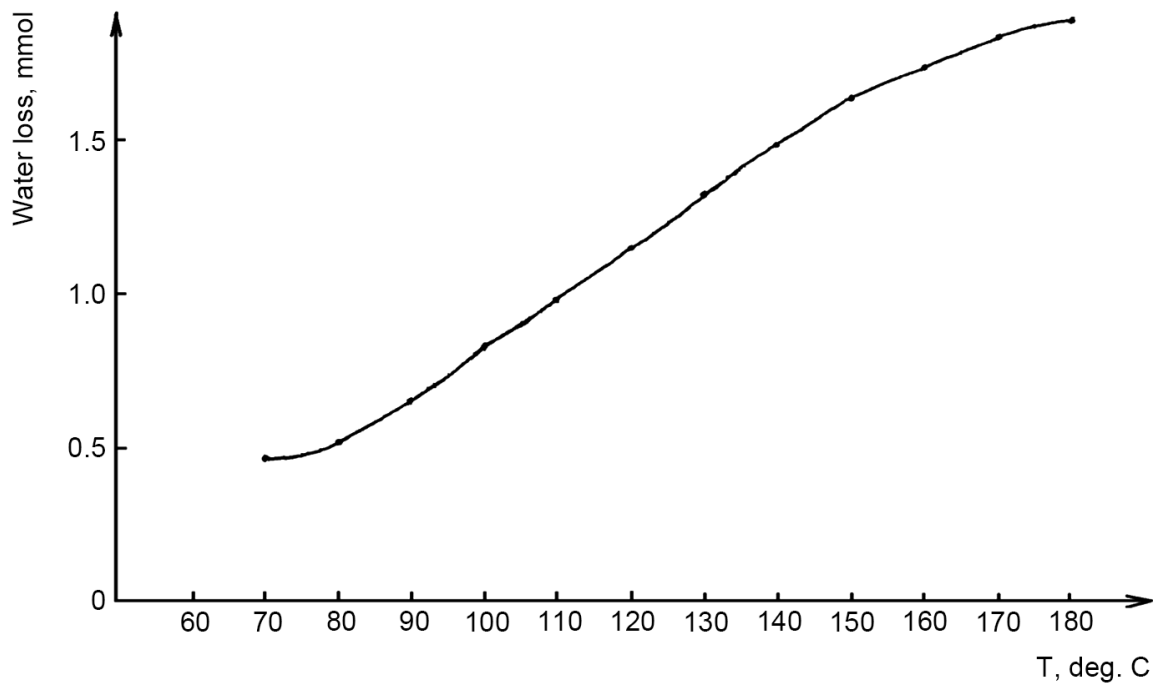

Figure 6. TGA of pectin dried beforehand $\left(120^{\circ} \mathrm{C}, 8\right.$ hours $)$.

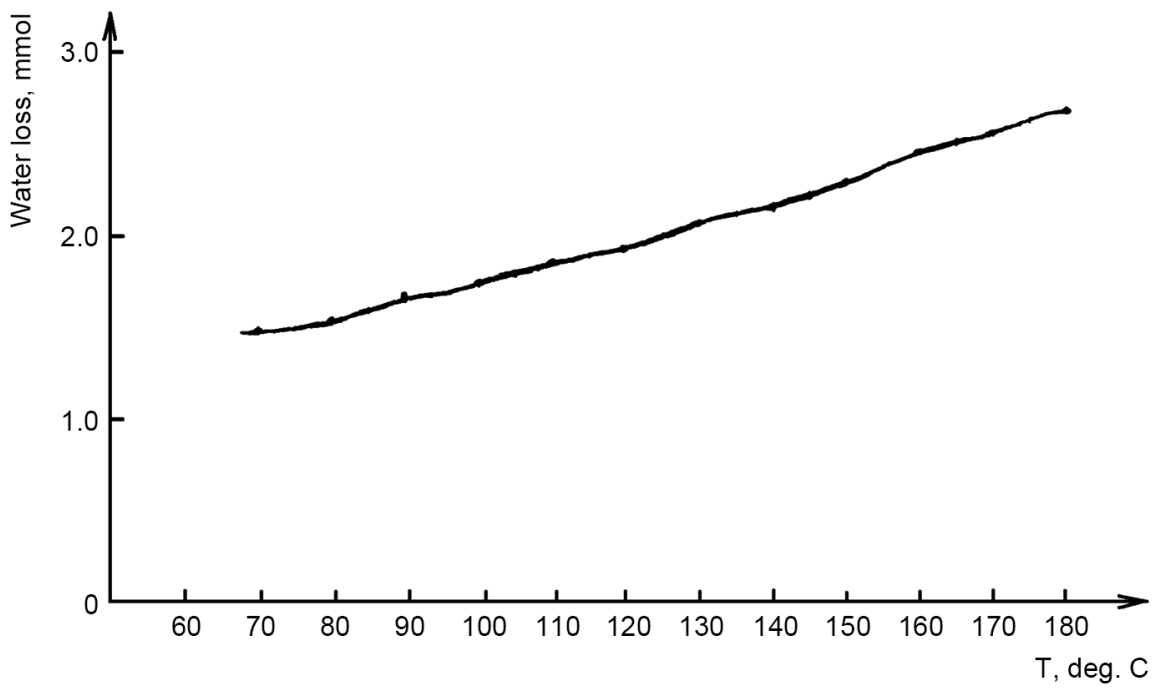

Figure 7. TGA of $\mathrm{ACu}^{2+}$ dried beforehand $\left(120^{\circ} \mathrm{C}, 8\right.$ hours $)$.

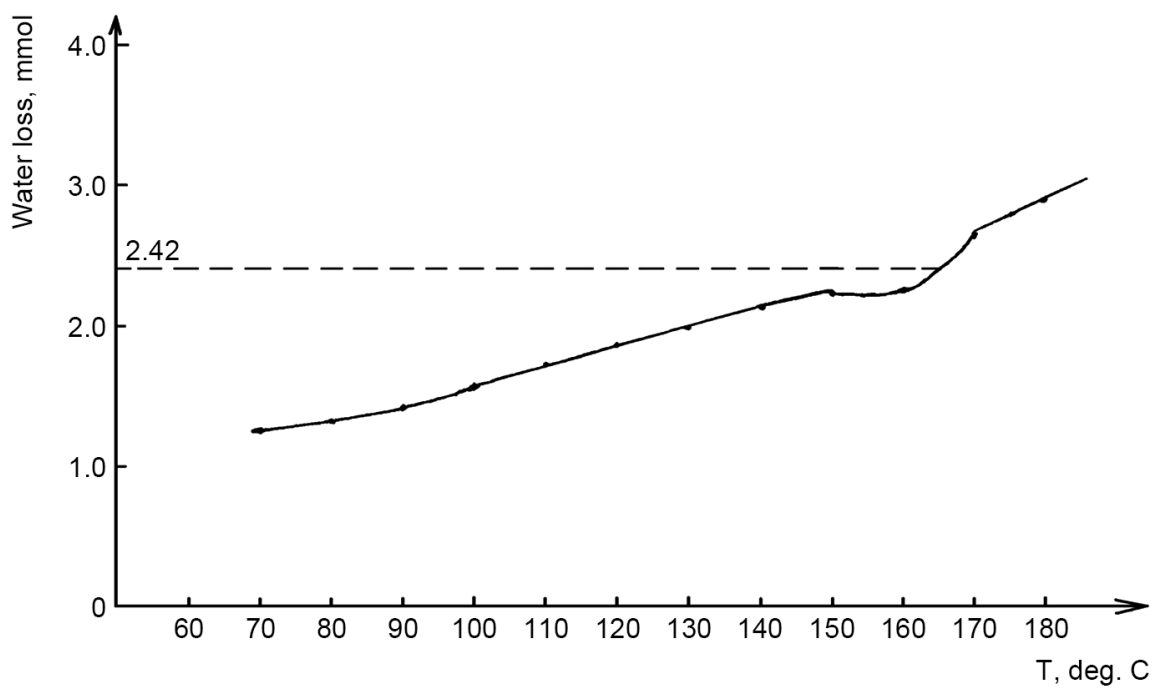

Figure 8. TGA of $\mathrm{PCu}^{2+}$ dried beforehand $\left(120^{\circ} \mathrm{C}, 8\right.$ hours $)$. 
Table 2. Data of TGA of pectin, $\mathrm{ACu}^{2+}, \mathrm{PCu}^{2+}$.

\begin{tabular}{ccccccc}
\hline & \multicolumn{5}{c}{ Amount of removed water } \\
\cline { 2 - 7 } $\mathrm{T},{ }^{\circ} \mathrm{C}$ & \multicolumn{2}{c}{ Pectin } & \multicolumn{2}{c}{$\mathrm{ACu}^{2+}$} & \multicolumn{2}{c}{$\mathrm{PCu}^{2+}$} \\
\cline { 2 - 7 } & $\mathrm{mg}$ & $\mathrm{mmol}$ & $\mathrm{mg}$ & $\mathrm{mmol}$ & $\mathrm{mg}$ & $\mathrm{mmol}$ \\
\hline 70 & 8.4 & 0.452 & 26.68 & 1.482 & 22.47 & 1.248 \\
80 & 9.40 & 0.522 & 28.28 & 1.571 & 23.90 & 1.328 \\
90 & 11.59 & 0.644 & 30.28 & 1.682 & 25.33 & 1.407 \\
100 & 14.78 & 0.821 & 31.72 & 1.762 & 28.73 & 1.596 \\
110 & 17.51 & 0.973 & 33.23 & 1.846 & 31.34 & 1.741 \\
120 & 20.59 & 1.144 & 34.96 & 1.942 & 33.46 & 1.859 \\
130 & 23.81 & 1.323 & 37.15 & 2.064 & 35.85 & 1.992 \\
140 & 26.66 & 1.481 & 38.93 & 2.163 & 38.54 & 2.141 \\
150 & 29.20 & 1.622 & 41.49 & 2.305 & 40.32 & 2.240 \\
160 & 30.96 & 1.720 & 44.14 & 2.452 & 41.04 & 2.280 \\
170 & 33.16 & 1.842 & 46.46 & 2.581 & 47.80 & 2.656 \\
180 & 33.89 & 1.883 & 48.31 & 2.684 & 52.27 & 2.904 \\
\hline
\end{tabular}

i.e. $\mathrm{PCu}^{2+}$ composition is expressed by the simplest formula $\left[\mathrm{Cu}\left(\mathrm{L}^{-}\right)_{2}\left(\mathrm{H}_{2} \mathrm{O}\right)_{2}\right]$. These results suggest that when dealing of pectin with $\mathrm{Cu}^{2+}$ ions there is a partial replacement of water molecules in the hydration shell of $\mathrm{Cu}^{2+}$ ions to $\mathrm{L}^{-}$.

Analysis of the $\mathrm{PPb}^{2+}$ composition. Feature comparison of pectin thermograms $\mathrm{APb}^{2+}$ and $\mathrm{PPb}^{2+}$ (Table 3) indicates the presence of the first (endothermic) effect in the temperature range $80^{\circ} \mathrm{C}-115^{\circ} \mathrm{C}(\mathrm{DTGA})$ and $100^{\circ} \mathrm{C}-120^{\circ} \mathrm{C}$ (DTA), which corresponds to the loss in weight on the TGA curves, this mass are referred to the loss of the adsorption water: $17.2 \%$ for pectin, $13.5 \%$ for $\mathrm{APb}^{2+}, 9.4 \%$ for $\mathrm{PPb}^{2+}$.

The conclusion about the loss of adsorption water is confirmed by the results of the quantitative determination of substances mass after drying $\left(120^{\circ} \mathrm{C}, 8\right.$ hours): reduction of pectin weight is $17.2 \%$ (from $0.57942 \mathrm{~g}$ to $0.47976 \mathrm{~g}$ ), $\mathrm{APb}^{2+}$ $13.5 \%$ (from $0.53274 \mathrm{~g}$ to $0.46082 \mathrm{~g}$ ), $\mathrm{PPb}^{2+}-9.4 \%$ (from $0.56358 \mathrm{~g}$ to $0.51060 \mathrm{~g}$ ). Unlike reagents for $\mathrm{PPb}^{2+}$ a "high temperature" component $\left(150^{\circ} \mathrm{C}-160^{\circ} \mathrm{C}\right)$ is discovered.

Comparative analysis of the curves of alkalimetric titration shows that if during pectin titration (Figure 4) the endpoint occurs as $\mathrm{pH} 9.14, \mathrm{APb}^{2+}$ (Figure 9, curve 1) $\mathrm{pH} 7.84(\Delta \mathrm{pH} / \Delta \mathrm{V}=2.84)$, then during titration $\mathrm{PPb}^{2+}$ (Figure 9, curve 2) $\mathrm{pH} 4.95(\Delta \mathrm{pH} / \Delta \mathrm{V}=1.83)$. For $\mathrm{PPb}^{2+}$ the presence of the endpoint in an acidic environment shows the demonstration of its acidic properties with hydroxycomplexes formation.

Thus, the occurring of a "high-temperature" component $\left(150^{\circ} \mathrm{C}-160^{\circ} \mathrm{C}\right)$ in $\mathrm{PPb}^{2+}$ and the demonstration of its acidic properties by reacting with alkali ( $\mathrm{pH}$ 4.95) proves the existence of water molecules in the internal sphere of CC, which is not observed for reagents. 
Table 3. Thermal characteristics of $\mathrm{PPb}^{2+}$ and reagents.

\begin{tabular}{|c|c|c|c|}
\hline $\begin{array}{l}\text { Effect of DTA } \\
\left(\mathrm{T}_{1}-\mathrm{T}_{2}\right),{ }^{\circ} \mathrm{C}\end{array}$ & Nature of the effect & $\begin{array}{c}\text { Effect of DTGA } \\
\left(\mathrm{T}_{1}-\mathrm{T}_{2}\right),{ }^{\circ} \mathrm{C}\end{array}$ & $\begin{array}{c}\text { Total weight } \\
\text { loss, } \%\end{array}$ \\
\hline \multicolumn{4}{|c|}{ Pectin } \\
\hline $100-115(\max 113)$ & $\downarrow$ desolvation & $80-105(\max 105)$ & \\
\hline $190-210(\max 200)$ & $\downarrow$ destruction of carboxyl groups & $210-230(\max 230)$ & \\
\hline $230-260(\max 240)$ & $\downarrow$ destruction for 1,4 -glycosidic bonds & $255-270(\max 265)$ & 98.0 \\
\hline $420-450$ & $\downarrow$ destruction & $410-415(\max 415)$ & \\
\hline \multicolumn{4}{|c|}{$\mathrm{APb}^{2+}$} \\
\hline $100-110(\max 105)$ & $\downarrow$ desolvation & $100-115(\max 110)$ & 704 \\
\hline $275-320(\max 280)$ & $\downarrow$ destruction with melting & $300-350(\max 310)$ & \\
\hline \multicolumn{4}{|c|}{$\mathrm{PPb}^{2+}$} \\
\hline $110-120(\max 110)$ & $\downarrow$ desolvation & $80-110(\max 110)$ & \\
\hline $150-158(\max 155)$ & $\downarrow$ desolvation & $150-160(\max 157)$ & \\
\hline $190-220(\max 220)$ & $\downarrow$ destruction of carboxyl groups & $215-235(\max 235)$ & 73.0 \\
\hline $245-250(\max 250)$ & $\downarrow$ destruction for 1,4-glycosidic bonds & $250-255(\max 250)$ & \\
\hline $340-530$ & $\downarrow$ destruction & $350-500(\max 380)$ & \\
\hline
\end{tabular}

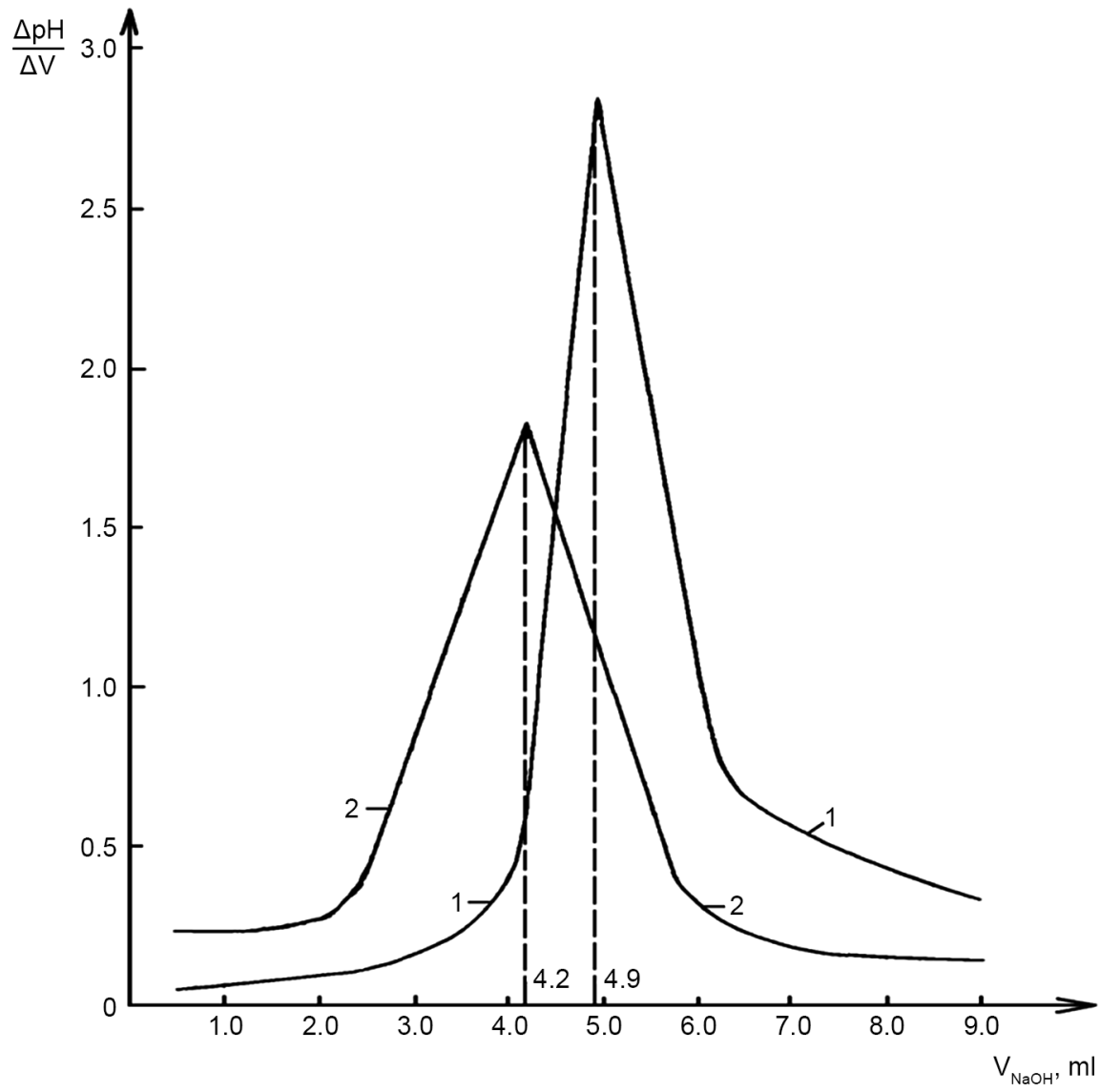

Figure 9. The curves of alkalimetric titration $\mathrm{APb}^{2+}$ (curve 1) and $\mathrm{PPb}^{2+}$ (curve 2). 


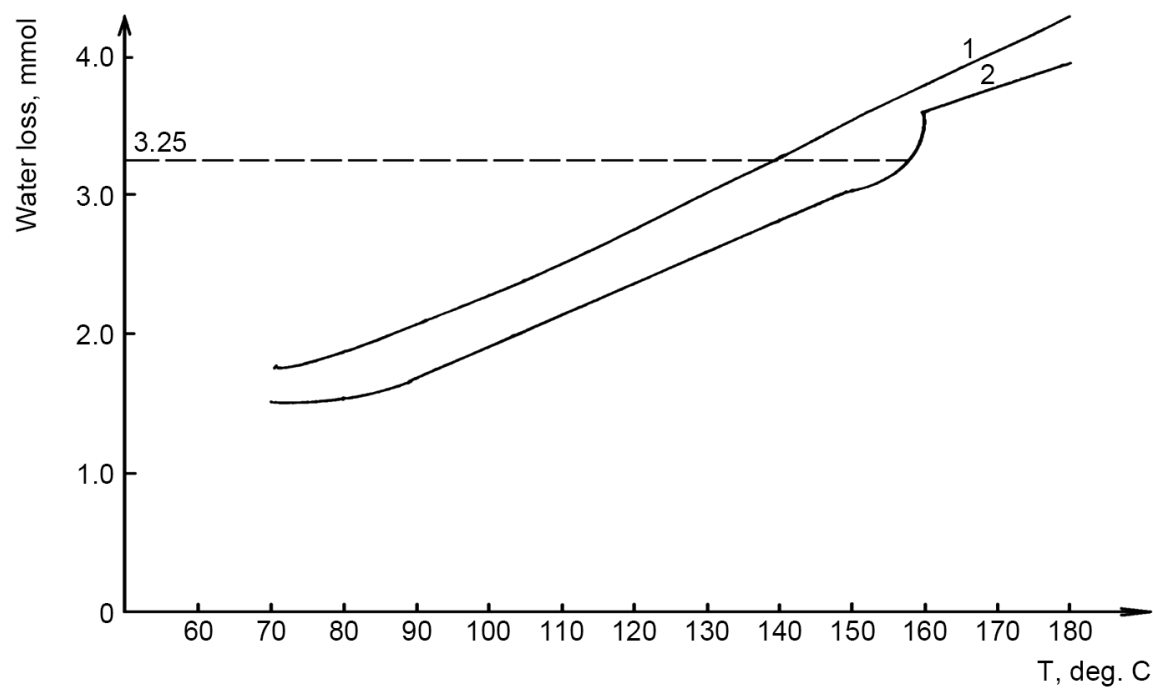

Figure 10. $\mathrm{TGA} \mathrm{APb}^{2+}$ (curve 1) and $\mathrm{PPb}^{2+}$ (curve 2) dried beforehand $\left(120^{\circ} \mathrm{C}, 8\right.$ hours).

As follows from TGA the presence of intracoordination water is not observed neither for pectin (Figure 6), nor for $\mathrm{APb}^{2+}$ (Figure 10, curve 1). Unlike them, in TGA of $\mathrm{PPb}^{2+}$ (Figure 10, curve 2) "ground", corresponding intracoordination water $\left(150^{\circ} \mathrm{C}-160^{\circ} \mathrm{C}\right.$ ), is detected, and its amount is $3.25 \mathrm{mmol}$ (or 0.05850 g). The mass difference of aquacomplex $\mathrm{PPb}^{2+}(0.51060 \mathrm{~g})$ and intracoordination water $(0.05850 \mathrm{~g})$ indicates the mass of anhydrous $\mathrm{PPb}^{2+}(0.45210 \mathrm{~g})$. Considering the molar ratio in $\mathrm{PPb}^{2+}$ of $\mathrm{Pb}^{2+}$ ions and $\mathrm{L}^{-}$1:2 (37.19 wt\%:62.81 wt\%) [6], $\mathrm{Pb}^{2+}$ ion content $(0.16814 \mathrm{~g}$ or $0.811 \mathrm{mmol})$ and $\mathrm{L}^{-}(0.28396 \mathrm{~g}$, or $1.623 \mathrm{mmol})$ is calculated.

Thus, the composition $\mathrm{PPb}^{2+}$, released from adsorption water, is expressed by the following ratios of $\mathrm{Pb}^{2+}$ ions, $\mathrm{L}^{-}$and molecules of coordination water: by mass $(\mathrm{g})-0.16814: 0.28396: 0.05850$; by the number $(\mathrm{mmol})-0.811: 1.623: 3.25$, or $1: 2: 4$, i.e. $\mathrm{PPb}^{2+}$ composition is expressed by the simplest formula $\left[\mathrm{Pb}\left(\mathrm{L}^{-}\right)_{2}\left(\mathrm{H}_{2} \mathrm{O}\right)_{4}\right]$. The relative error of determining is $3.1 \%-4.8 \%$.

\section{Conclusion}

The presence of intarcoordination water in the composition of $\mathrm{PCu}^{2+}$ and $\mathrm{PPb}^{2+}$ is proven by the method of derivatography by the endothermic effect exceeding $150^{\circ} \mathrm{C}$ (respectively, as $150^{\circ} \mathrm{C}-165^{\circ} \mathrm{C}$ and $150^{\circ} \mathrm{C}-160^{\circ} \mathrm{C}$ ), and by potentiometric alkalimetric titration by formation of hydroxycomplexes in a weakly acidic medium (respectively as $\mathrm{pH}$ at the equivalence points is 4.87 and 4.95 ). By thermogravimetrically established quantitative loss of intracoordination water mass, based on the known ratio of the metal cations and $\mathrm{L}^{-}$, the $\mathrm{CC}$ compositions are determined and expressed by the formula: $\left[\mathrm{Cu}\left(\mathrm{L}^{-}\right)_{2}\left(\mathrm{H}_{2} \mathrm{O}\right)_{2}\right],\left[\mathrm{Pb}\left(\mathrm{L}^{-}\right)_{2}\left(\mathrm{H}_{2} \mathrm{O}\right)_{4}\right]$. The results are needed to determine the minimum and therapeutic doses of pectins, as an antidote for poisoning compounds of $\mathrm{Cu}^{2+}$ and $\mathrm{Pb}^{2+}$.

\section{References}

[1] Kabelitz, Z. (1998) Zur Schwermetallbelastung von Arzneu-und Krauterdrogen. 
Pharmaceutical Industries, 60, 444-451.

[2] Ershov, Y. and Pleteneva, T. (1989) Mechanisms of Toxic Effect of Inorganic Compounds. Medicine, Moscow, 272.

[3] Linde, K. and Donas, W. (1994) Clinical Review and Meta Analysis of Serial Agitaled Dilutions in Experimental Toxicity. Human and Experimental Toxicology, 13, 481-492. https://doi.org/10.1177/096032719401300706

[4] Corsello, S. and Ghen, M. (2000) Cellular Detoxification: An Integrative Approach to Anti-Aging. International Journal of Integrative Medicine, 2, 19-26.

[5] Crinnion, W. (2000) Environmental Medicine, Part 1: The Human Burden of Environmental Toxins and Their Common Health Effects. Alternative Medicine Review, 5, 52-63.

[6] Kaysheva, N. and Kaishev, A. (2016) Pharmacochemical Basis for the Use of Pectins and Alginates. RIA-KMV, Pyatigorsk, 260.

[7] Mashkovskii, M. (2012) Drugs: In 2 v. New Wave, Moscow, Vol. 1, 628, Vol. 2, 580.

[8] Serban, A. (1995) Neue, Chelatbildner Enthaltende Arzneimittel. Patent DE4431175, IPC A61K31/195, No. P4431175.3, 11.

[9] Kondakova, V. (1998) Detoxicator to Overcome Drug Addiction and Intoxication of Chemicals and Endogenous Genesis. Patent 2108101RF, A61K33/06, No. 96103095/14, 10 .

[10] Domingo, J. (1996) Adverse Effects of Aluminium Chelating Compounds for Clinical Use. Adverse Drug Reactions and Toxicological Reviews, 15, 145-165.

[11] Singleton, K. (2000) Adverse Effects in 5 Patients Reserving EDTA in an Outpatient Chelation Clinic. Journal of Clinical Toxicology, 38, 549-550.

[12] Dawson, R. (1991) Reference Book of a Biochemist. Mir, Moscow, 544.

[13] Williams, D. (1975) Metals of Life. Mir, Moscow, 238.

[14] Ismailova, M., Ismailov, P. and Mahkamov, H. (2000) High Efficiency Carbon Sorbent of Medical Prescription from Cotton Lignin. Chemical and Pharmaceutical Journal, 34, 38-40.

[15] Nikolaev, B. (1996) Activated Carbon Fiber Enterosorbent. Patent 2057533RF, IPC A61K33/44, No. 5049704/14, 9.

[16] Zhuravskaya, N. (1998) The Method of Detoxification of Workers of Chemical Plants. Patent 2115414 RF, IPC A61K9/18, No. 95105846/14, 11.

[17] Foteev, V. (2002) Enterosorbent. Patent 2180231RF, IPC A61K35/78, No. 2000100751/ 14,11 .

[18] Kennedy, R. and Stewart, P. (1996) The Kinetics of Calcium and Magnesium Ions on to an Insoluble Sodium Polyphosphate. Drug Development and Industrial Pharmacy, 22, 697-703.

[19] Zhubanova, A. and Mansurov, Z. (1999) Synthesis of Carbon Mineral Sorbents and Their Use in Medicine. Med. Raw mater. and Phytoprep. med. and Agr.: Tes. Book Abstr. Int. Conf., Karaganda, 94.

[20] Alekseev, Y., Garnovskii, A. and Zhdanov, Y. (1998) Natural Carbohydrate Complexes with Metal Cations. Advance in Chemistry, 67, 723-744.

[21] Usov, A. (1992) Pectins. Chem. Encyclopedia, 3, 452-453.

[22] Vasilenko, Y. and Kaysheva, N. (2003) The Mechanism for Detoxifying Action of Acidic Polysaccharides with Lead Intoxication in Rats. Chemical and Pharmaceutical Journal, 37, 12-15.

[23] Kaysheva, N., Vasilenko, Y. and Kaishev, A. (2014) The Effect of Polyuronides on 
Elimination of Certain Metals. Pharmacy, 2, 41-45.

[24] Kaysheva, N. and Kaishev, A. (2015) Composition and Durability of Metal Pectinates (II) and Alginates in Aqueous Solution According to Potentiometric Titration Data. Journal of Physical Chemistry, 89, 1122-1128.

[25] Kaysheva, N., Vasilenko, Y. and Sajaya, L. (2002) Preventive Agent Having Detoxifying Activity. Patent 2191590RF, IPC A61K35/78, No. 2001112679/14, 36.

[26] Kompantsev, V., Utkina, E. and Kaysheva, N. (1992) Process for Preparing Pectinates Having Antimicrobial Activity. Copyright Certificate 1776656USSR, IPC C08B 37/06, No. 4788377/05, 10.

[27] Kaysheva, N. and Kaishev, A. (2015) The Method for Determination of Water in Coordination Compounds. Patent 2555360 RF, IPC G01N 31/16, No. 2012147095/ $15,22$.

[28] Zheligovskaya, N. and Chernyaev, I. (1966) Chemistry of Complex Compounds. High School, Moscow, 388.

[29] Filippov, M. (1976) Dependence Colorimetric Reaction of Galacturonic Acid and Neutral Monosaccharides with Carbazole and the Conditions of Its Performance. Proceedings of the Mold. Series of Biology and Chemical Sciences, Vol. 1, SSR, Kiev, 75-86.

[30] Kurylenko, O., Fabulyak, J. and Klimovich, V. (1975) IR-Spektroskopie at Adsorption Water by Apple Pectin and Its Natrium Compound. Series: Geology, Geophysics, Chemistry and Biology, Vol. 4, National Academy of Sciences of Ukrainian SSR, Kiev, 332-334.

[31] Kaysheva, N. (2003) The Method for Determination of Functional Groups of Polyuronides. Patent 2206089 RF, IPC G 01 N 31/16, No. 2001134132/04, 30.

[32] Spitsyna, V. and Martynenko, L. (1979) Coordination Chemistry of Rare Earth Elements. Moscow State University, Moscow, 285.

[33] Kharitonov, Y. (2005) Analytical Chemistry (Analytics). Quantitative Analysis. Physical and Chemical (Instrumental) Methods of Analysis. High School, Moscow, 559.

Submit or recommend next manuscript to SCIRP and we will provide best service for you:

Accepting pre-submission inquiries through Email, Facebook, LinkedIn, Twitter, etc. A wide selection of journals (inclusive of 9 subjects, more than 200 journals)

Providing 24-hour high-quality service

User-friendly online submission system

Fair and swift peer-review system

Efficient typesetting and proofreading procedure

Display of the result of downloads and visits, as well as the number of cited articles

Maximum dissemination of your research work

Submit your manuscript at: http://papersubmission.scirp.org/

Orcontact ajac@scirp.org 